\title{
Primary Pleural Liposarcoma: A Case Report
}

\author{
Primer Plevral Liposarkoma: Olgu Sunumu
}

Ayman Ahmed', Hüseyin Melek', Ulviye Yalçınkaya², Ahmet Sami Bayram'

\section{Abstract}

Primary pleural liposarcoma is a rare tumor; only a few cases have been reported in the literature. Presently described is the case of a 77-year-old female with a right pleural-based tumor misinterpreted as loculated pleural effusion, who was suffering from chronic right-sided chest pain. Radical resection of the tumor was performed and revealed a welldifferentiated pleural liposarcoma. This case is discussed with a review of the literature.

Key words: Pleural liposarcoma, loculated pleural effusion, primary pleural tumor.

\section{Özet}

Primer plevral liposarkoma literatürde birkaç olguluk seriler olarak tanımlanan nadir görülen bir tümördür. Biz bu yazımızda, sağ plevral tabanlı olup ilk değerlendirmede plevral efüzyon olarak yorumlanan ve sağ göğüs duvarı ağrısı olan 77 yaşında bayan hastamızı sunduk. Kitleye radikal cerrahi rezeksiyon yapıldıktan sonra tanı iyi difensiye plevral liposarkoma geldi. Yazımızda olguyu literatür eşliğinde tartıştık.

Anahtar Sözcükler: Plevral liposarkom, loküle plevral efüzyon, primer plevral tümör.
Primary pleural neoplasms are uncommon; they represent $10 \%$ of pleural tumors. The pleura is more commonly involved with a secondary or metastatic neoplasm from the lung or breast, lymphoma, and ovary or gastric carcinoma. Mesothelioma is the most frequent primary pleural tumor, accounting for some $90 \%(1,2)$. Primary pleural liposarcoma (PPL) is derived from primitive mesenchymal tissue. There are fewer than 20 cases of PPL described in the literature (3).

\section{CASE}

A 77-year-old female patient, presented with a 3year history of dull, right-sided chest pain, a nonproductive cough, and progressive shortness of breath. She was a nonsmoker, but she had a history of exposure to asbestos. A clinical examination was unremarkable apart from diminished air entry in the right lower chest. A chest $\mathrm{X}$-ray with frontal projection illustrated homogenous, right mid and lower zone opacity with well circumscribed margins (Figure 1a), and a computed tomography (CT) scan of the chest with contrast revealed a well circumscribed soft tissue mass with lobulated margins in the right lower pleural space compressing the right lower lobe (Figures $1 c$ and d) that was suggestive of a fatty tissue mass/loculated effusion. An attempt to perform ultrasound-guided thoracentesis failed.

A right posterolateral thoracotomy was performed and revealed a large, well-encapsulated fatty mass, $16 \times 14 \mathrm{~cm}$ in size, compressing the right lower lobe, resting on the diaphragm, and arising from the lateral chest wall parietal pleura. The mass

'Department of Thoracic Surgery, Uludağ University Faculty of Medicine, Bursa, Turkey

'Uludağ Üniversitesi Tıp Fakültesi,Göğüs Cerrahisi Anabilim Dalı, Bursa

${ }^{2}$ Department of Pathology, Uludağ University Faculty of Medicine, Bursa, Turkey

${ }^{2}$ Uludağ Üniversitesi Tıp Fakültesi, Patoloji Anabilim Dalı, Bursa

Submitted (Başvuru tarihi): 1 1.08.2017 Accepted (Kabul tarihi): 26.10.2017

Correspondence (iletişim): Ayman Ahmed, Department of Thoracic Surgery, Uludağ University Faculty of Medicine, Bursa, Turkey 
was dissected free from the surrounding tissue and extirpated (Figure 2). A parietal pleurectomy at the tumor base was done to ensure adequate tumor excision. The postoperative course was uneventful (Figure 1b). Microscopic sections of the tumor showed atypical mononuclear, multinuclear lipoblastic cells of various sizes with hyperchromatic nuclei, and areas of sclerosis with fibrous tissue bands. No necrosis was present. Histopathology examination confirmed the diagnosis of a welldifferentiated variant of pleural liposarcoma (Figure 3) with a negative surgical margin. The management plan was discussed by the hospital tumor board, and the decision was made not to pursue adjuvant radiotherapy or chemotherapy, considering the patient's age, tumor histology, and the negative surgical margin.

The patient was followed up regularly for 2 years and no local recurrence or distant metastasis was observed.

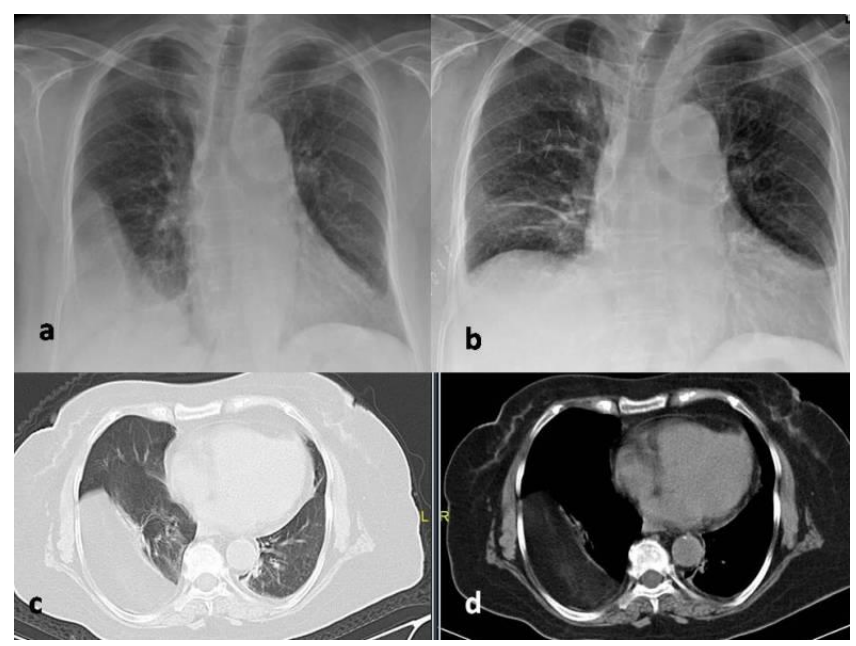

Figure $1 a, b, c$ and $d$ : Preoperative chest $X$-ray (a), postoperative ches $X$-ray (b), and preoperative chest computed tomography images (c and d)

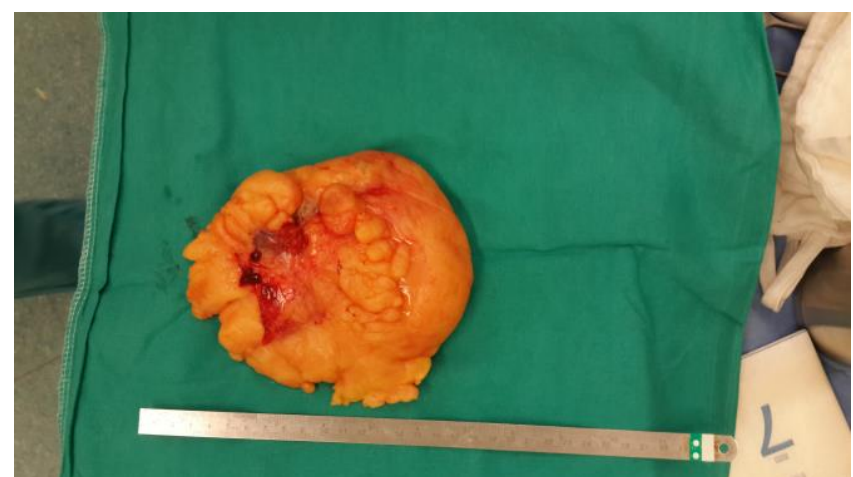

Figure 2: Gross pathological specimen

\section{DISCUSSION}

Primary pleural liposarcoma (PPL) is thought to be derived from residual nests of primitive mesenchymal cells in the pleural cavity. Histological subtypes include the myxoid, pleomorphic, dedifferentiated, and well-differentiated types. The myxoid subtype is the most common variant. Poor disease-free survival and Inferior overall-survival have been observed in the dedifferentiated, pleomorphic, and myxoid types $(4,5)$.

There is a great range of biological behavior among these subtypes, from well-differentiated liposarcoma with a low metastatic potential to the high-risk round cell or pleomorphic types, which tend to be higher grade and are associated with a high rate of distant metastases (6).

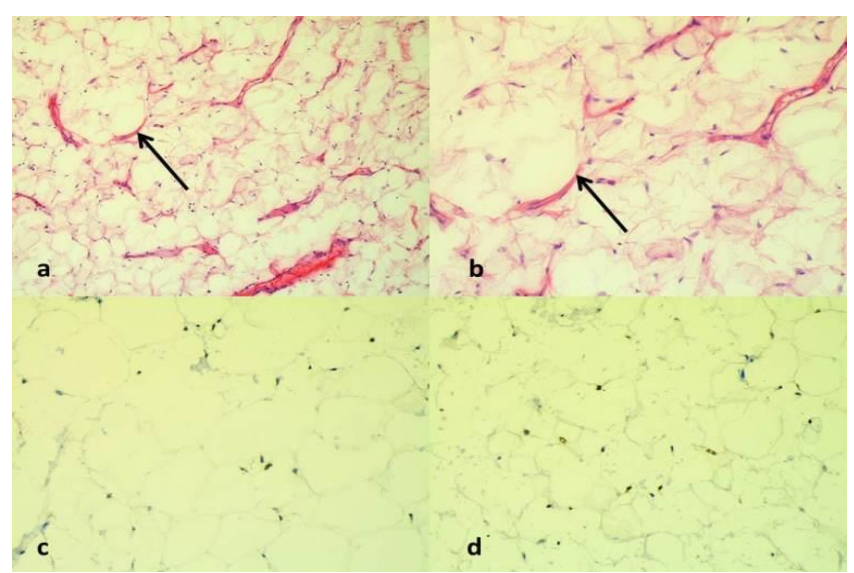

Figure 3a, b, $c$ and d: Histopathology of the excised tumor. Marked variation in adipocyte size, delicate arborizing vasculature, and atypical hyperchromatic stromal cells (black arrow) H\&E x100 (a); Atypical hyperchromatic stromal cells (black arrow) H\&E x200 (b); Nuclear staining pattern of MDM2, (c); Nuclear staining pattern of CDK4 (d)

PPL is a slow-growing tumor with a low potential for invasion. The main presenting symptoms are due to the effects of pressure on surrounding structures, and nonspecific symptoms, including a cough, chest pain, and shortness of breath. Sometimes the tumor is discovered incidentally during routine chest radiography (3).

Among 16 documented cases of patients between the ages of 19 and 80 years (mean of 50 years), PPL was more frequent in men (11 men and 5 women) (3).

Macroscopically, PPL is nodular, lobular, and has a gelatinous appearance. A series of 4 patients reported by Okby and Travis (7), described tumors with a largest diameter of 16 to $20 \mathrm{~cm}$ and weighing up to $1.868 \mathrm{~g}$.

Accurate diagnosis relies on careful interpretation of a radiological finding on a chest radiography and $\mathrm{CT}$, with particular attention paid to tumor location, density, and relationship to the lungs, chest wall and mediastinum (7). The tumor size, histological type, and radical surgery are the factors that influence the prognosis of PPL (5). Enzinger and Winslow (8) reported that the 5-year survival rate of patients with well-differentiated and myxoid forms 
exceeded 75\%, whereas in the round cell and pleomorphic varieties, it was only about $20 \%$.

Radical surgery followed by adjuvant radiotherapy may benefit patients with PPL (7). In our case, as the patient was elderly, had a poor performance status, a favorable histological subtype (well differentiated), and a negative margin, no adjuvant radiotherapy was given.

In conclusion, patients with well-differentiated pleural liposarcoma causing localized symptoms can be successfully managed with radical resection and tumor free margins without adjuvant radiation therapy. Our patient was doing well and was symptom-free without any recurrence or distant metastasis for 24 months after following this treatment plan.

\section{CONFLICTS OF INTEREST}

None declared.

\section{AUTHOR CONTRIBUTIONS}

Concept - A.A., H.M., U.Y., A.S.B.; Planning and Design - A.A., H.M., U.Y., A.S.B.; Supervision - A.A., H.M., U.Y., A.S.B.; Funding - A.S.B.; Materials - U.Y.; Data Collection and/or Processing - A.A.; Analysis and/or Interpretation - A.A., A.S.B.; Literature Review - H.M.; Writing A.A.; Critical Review - A.A., A.S.B.

\section{YAZAR KATKILARI}

Fikir - A.A., H.M., U.Y., A.S.B.; Tasarım ve Dizayn - A.A., H.M., U.Y., A.S.B.; Denetleme - A.A., H.M., U.Y., A.S.B.; Kaynaklar - A.S.B., M.Ç.; Malzemeler - U.Y.; Veri Toplama ve/veya İşleme - A.A.; Analiz ve/veya Yorum - A.A., A.S.B.; Literatür Taraması - H.M.; Yazıyı Yazan - A.A.; Eleştirel İnceleme - A.A., A.S.B.

\section{REFERENCES}

1. Bonomo L, Feragalli B, Sacco R, Merlino B, Storto ML. Malignant pleural disease. Eur J Radiol 2000; 34:98118. [CrossRef]

2. Gebhard S, Coindre JM, Michels JJ, Terrier P, Bertrand G, Trassard M, et al. Pleomorphic liposarcoma: clinicopathologic, immunohistochemical, and follow-up analysis of 63 cases: a study from the French Federation of Cancer Centers Sarcoma Group.Am J SurgPathol 2002; 26:601-16. [CrossRef]

3. Carrillo B JA, Navarrete C, López Arias MA, Peláez M. Primary pleural liposarcoma, pleomorphic variant. J Thorac Dis 2014; 6:E166-8. [CrossRef]

4. Granville L, Laga AC, Allen TC, Dishop M, Roggli VL, Churg $A$, et al. Review and update of uncommon primary pleural tumors: a practical approach to diagnosis. Arch Pathol Lab Med 2005; 129:1428-43.

5. Chen M, Yang J, Zhu L, Zhou C, Zhao H. Primary intrathoracic liposarcoma: a clinicopathologic study and prognostic analysis of 23 cases. J Cardiothorac Surg 2014; 9:119. [CrossRef]

6. Ghadimi MP, Liu P, Peng T, Bolshakov S, Young ED, Torres KE, et al. Pleomorphic liposarcoma: clinical observations and molecular variables. Cancer 2011; 117:5359-69. [CrossRef]

7. Okby NT, Travis WD. Liposarcoma of the pleural cavity: clinical and pathologic features of 4 cases with a review of the literature. Arch Pathol Lab Med 2000; 124:699. 703.

8. Enzinger FM, Winslow DJ. Liposarcoma, a study of 103 cases. Virchows Arch Pathol Anat Physiol Klin Med 1962; 335:367-88. 